\title{
Maize catalases localized in peroxisomes support the replication of maize chlorotic mottle virus
}

\author{
Zhiyuan Jiao, Juan Wang, Yiying Tian, Siyuan Wang, Xi Sun, Siqi Li, Wendi Ma, Tao Zhou and Zaifeng Fan * (D)
}

\begin{abstract}
Co-infection of maize chlorotic mottle virus (MCMV) with a virus in the Potyviridae family, such as sugarcane mosaic virus, usually leads to maize lethal necrosis (MLN). Over the past decade, MCMV/MLN has emerged in many countries/regions of the world and resulted in serious yield loss in maize production. Although partial functions of some MCMV-encoded proteins have been identified, the host factors related to MCMV replication are poorly understood. Here, we show that maize peroxisomes can form aggregated bodies in MCMV-infected leaf cells. The dsRNA binding-dependent fluorescence complementation assay indicated that the aggregated peroxisomes in maize served as the major replication site of MCMV. In addition, our results revealed that all the three maize catalases were present mostly in peroxisomes in the presence or absence of MCMV. Furthermore, we determined that inhibition of catalase activity or induction of reactive oxygen species (ROS) in maize protoplasts significantly reduced the accumulation of MCMV RNA. In summary, this research reveals the replication site of MCMV and an important role of maize catalases in supporting virus replication. Our results are conducive to understanding the pathogenesis of MCMV and identifying targets for resistance breeding or gene regulation strategies.
\end{abstract}

Keywords: Catalase, Maize chlorotic mottle virus (MCMV), Peroxisome, Replication site, Virus replication

\section{Background}

Pathogenic infections in plants are frequently associated with the accumulation of reactive oxygen species (ROS), such as superoxide anion radical $\left(\cdot \mathrm{O}_{2}^{-}\right)$, hydroxyl radical $(\mathrm{OH})$ and hydrogen peroxide $\left(\mathrm{H}_{2} \mathrm{O}_{2}\right)$, which serve as signal transduction molecules to control a large array of biological processes, including senescence, growth and development, and biotic or abiotic stress responses (Schippers et al. 2012; Lehmann et al. 2015; Guo et al. 2017; Zhou et al. 2018). In photosynthetic cells, chloroplasts, mitochondria and peroxisomes are the major sites of intracellular ROS production (Mhamdi et al. 2010). The generation of ROS, known as the oxidative burst, is considered the earliest response of plant cells to biotic

\footnotetext{
*Correspondence: fanzf@cau.edu.cn

State Kay Laboratory of Agrobiotechnology and Key Laboratory of Pest Monitoring and Green Management-MARA, Department of Plant Pathology, China Agricultural University, Beijing 100193, China
}

stimuli (Vranova et al. 2002). In addition, as a watersoluble, long half-life and non-radical two-electron reduction product of oxygen, $\mathrm{H}_{2} \mathrm{O}_{2}$ is generated as an important messenger to induce downstream defense proteins. Since increased ROS production during pathogen attack triggers accumulation of salicylic acid, induces pathogenesis-related protein genes and even cell death, the accumulation of ROS has been accepted as a hallmark of plant defense (Lamb and Dixon 1997; Dempsey et al. 1999). It is assumed that the generation of $\mathrm{H}_{2} \mathrm{O}_{2}$ at the correct time and location successfully hinders the penetration of pathogens into their host plants (Mellersh et al. 2002; Magbanua et al. 2007).

Although $\mathrm{H}_{2} \mathrm{O}_{2}$ is essential for signaling pathogen invasion and host defense, high level of $\mathrm{H}_{2} \mathrm{O}_{2}$ induces oxidative stress, ultimately resulting in cell and tissue death. To protect cells from the deleterious effects of $\mathrm{H}_{2} \mathrm{O}_{2}$, plants have evolved efficient enzymatic and non-

(c) The Author(s). 2021 Open Access This article is licensed under a Creative Commons Attribution 4.0 International License, which permits use, sharing, adaptation, distribution and reproduction in any medium or format, as long as you give appropriate credit to the original author(s) and the source, provide a link to the Creative Commons licence, and indicate if changes were made. The images or other third party material in this article are included in the article's Creative Commons licence, unless indicated otherwise in a credit line to the material. If material is not included in the article's Creative Commons licence and your intended use is not permitted by statutory regulation or exceeds the permitted use, you will need to obtain permission directly from the copyright holder. To view a copy of this licence, visit http://creativecommons.org/licenses/by/4.0/. 
enzymatic mechanisms to detoxify $\mathrm{H}_{2} \mathrm{O}_{2}$. Plants are capable of producing several types of enzymatic antioxidants (e.g. catalases and ascorbate peroxidases), peroxiredoxins, glutathione peroxidases and glutathione $\mathrm{S}$ transferases to metabolize $\mathrm{H}_{2} \mathrm{O}_{2}$ (Anjum et al. 2016). Among the $\mathrm{H}_{2} \mathrm{O}_{2}$-scavenging enzymes, catalase (CAT) is a highly conserved enzyme that catalyzes the decomposition of hydrogen peroxide $\left(\mathrm{H}_{2} \mathrm{O}_{2}\right)$ to produce water and oxygen and thus plays a critical role in plant disease resistance. CAT is a heme-containing enzyme that is found in diverse organisms, including prokaryotes, fungi, plants and animals (Chelikani et al. 2004). In higher plants, catalase is a tetrameric enzyme consisting of polypeptides of $50-70 \mathrm{kDa}$ (Mhamdi et al. 2010).

In maize (Zea mays L.), the catalase gene family is composed of three members that are encoded by three unlinked genes (ZmCAT1, ZmCAT2 and ZmCAT3) (Roupakias et al. 1980). As in some higher plants, three catalases in maize share reasonably high sequence similarity at the amino acid level (63-77\%) (Magbanua et al. 2007). Each of the catalase genes exhibits temporal and spatial specificity in its expression (Scandalios et al. 1984; Wadsworth and Scandalios 1989; Redinbaugh et al. 1990). For instance, ZmCAT1 is the only catalase isozyme expressed in milky endosperm, aleurone and scutellum during the early stages of kernel development (Guan and Scandalios 1993). ZmCAT2 is positively regulated by light in a tissue-specific manner, and the ZmCAT3 transcript shows a circadian rhythm, with a peak expression at the night/day transition (Skadsen and Scandalios 1987; Guan et al. 1996).

CAT is mainly localized in peroxisomes in higher plants. The non-cleaved tripeptide (S/T-R-L) at the extreme C-terminus of polypeptide have been identified for determining import of catalases into peroxisomes (Brown and Baker 2008; Mhamdi et al. 2010). ZmCAT1 and ZmCAT2 localize in the peroxisome (Abler and Scandalios 1993). ZmCAT3 might localize in the mitochondria since significant catalase activity (ZmCAT3) was detected in washed mitochondria (Scandalios et al. 1980). In addition, catalases play important roles in the interactions of host plants with viral pathogenicityrelated proteins (Inaba et al. 2011; Mathioudakis et al. 2013; Murota et al. 2017; Roshan et al. 2018; Yang et al. 2020; Jiao et al. 2021). For instance, Arabidopsis thaliana catalase 3 interacts with cucumber mosaic virus (CMV$\mathrm{HL}$ ) $2 \mathrm{~b}$ protein to inactivate the silencing suppressor activity of 2 b (Inaba et al. 2011). However, whether catalases affect viral replication remains largely unknown.

Maize chlorotic mottle virus (MCMV) is the only member of the genus Machlomovirus in the family Tombusviridae, and its host range is restricted to Poaceae (Scheets 2016). The MCMV genome consists of a positive-sense single-stranded RNA of 4437 nt without a $5^{\prime}$ cap or a poly (A) tail, and encodes seven proteins including P32, P50, P111, P7a, P7b, P31 and coat protein (CP) (Nutter et al. 1989; Scheets et al. 1993; Scheets 2016) (Fig. 1a). P32 locates at a region proximal to the 5 ' end of the viral genome, and is unique to MCMV in the family Tombusviridae (Nutter et al. 1989; Scheets 2016). The absence of P32 in MCMV dramatically decreases viral accumulation and symptoms in host plant (Scheets 2016). P50 and its readthrough protein P111 are replication proteins, similar with those in other viruses of the family Tombusviridae. Other four proteins (P7a, P31, P7b and CP) are expressed from subgenomic RNA1 (sgRNA1) (Scheets 2000, 2016). Mutagenesis analyses demonstrate that $\mathrm{P} 7 \mathrm{a}, \mathrm{P} 7 \mathrm{~b}$ and $\mathrm{CP}$ are required for cell-to-cell movement in maize plants (Scheets 2016). The MCMV CP interacts with the nuclear import factor importin- $\alpha$ for nuclear import, and silencing of the importin- $\alpha$ gene decreases MCMV accumulation (Zhan et al. 2016). Another unique protein P31 expressed as a readthrough extension of $\mathrm{P} 7 \mathrm{a}$ is required for efficient systemic infection (Scheets 2016; Jiao et al. 2021). P31 is the major pathogenicity determinant of MCMV, and its expression induces necrosis in systemically infected leaves (Jiao et al. 2021). A 337-nt noncoding sgRNA2 was detected in MCMV-infected maize protoplasts and plants (Scheets 2000). MCMV causes chlorotic, mottle symptoms and even necrosis in maize plants. In addition, it is part of a synergistic disease called maize lethal necrosis (MLN) (Goldberg and Brakke 1987; Scheets 1998; Xia et al. 2016; Wang et al. 2017). MLN is caused by a mixed infection of MCMV and a virus in the Potyviridae family, such as sugarcane mosaic virus (SCMV) (genus Potyvirus) (Scheets 1998; Xia et al. 2016; Wang et al. 2017), maize dwarf mosaic virus (MDMV) (genus Potyvirus) (Goldberg and Brakke 1987), Johnsongrass mosaic virus (JGMV) (genus Potyvirus) (Stewart et al. 2017) and wheat streak mosaic virus (WSMV) (genus Tritimovirus) (Scheets 1998). MLN is a devastating disease which can cause up to $100 \%$ yield loss (Redinbaugh and Stewart 2018). Over the past decade, the emergence of MLN has resulted in significant economic losses in many maize-growing countries/regions of the world (Redinbaugh and Stewart 2018). Although efforts were made to identify resistance against MCMV, no genes conferring complete resistance have been reported (Redinbaugh and Stewart 2018; Carino et al. 2020). Some mechanisms underlying MCMV pathogenesis have been elucidated (Inaba et al. 2011; Scheets 2016; Zhan et al. 2016; Carino et al. 2020; Jiao et al. 2021), however, little is known about its replication mechanisms. In this research, we focused on the molecular mechanisms of MCMV replication, aiming at providing valuable knowledge towards identifying targets for virus resistance. 


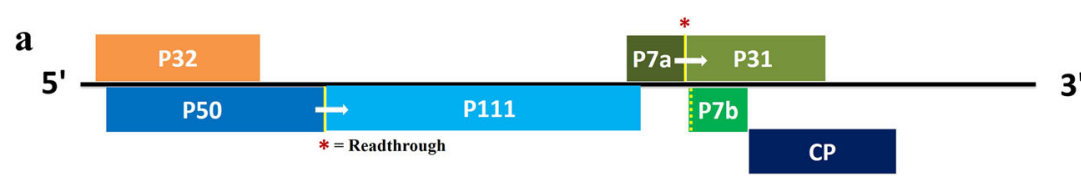

\section{3'}

sgRNA 1
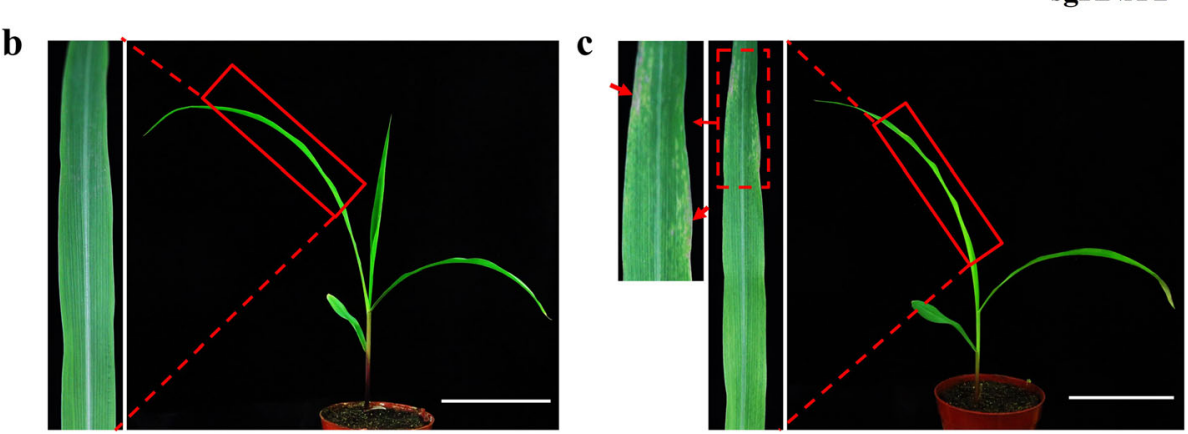

Fig. 1 Maize chlorotic mottle virus (MCMV) infection causes chlorosis and necrosis in maize leaves. a Genomic organization of MCMV. The heavy line indicates the genomic RNA and the thinner lines represent the subgenomic RNA1/2 (sgRNA1/2). Boxes indicate the coding regions and their open reading frames. The vertical lines (asterisks in red) indicate the leaky stop codons leading to translational readthrough. The dashed line (P7b) represents a non-AUG start codon. CP: coat protein. b, c Phenotypes in the first systemically infected maize leaves of mock-inoculated (b) or MCMV-inoculated (c) maize plants at 10 days post-inoculation (dpi). The red arrows indicate the necrotic regions. Bar, $10 \mathrm{~cm}$

Here, we reveal that MCMV infection can induce the formation of aggregated bodies of peroxisomes in host plants. Our results demonstrate that all three maize catalases are localized in peroxisomes where MCMV replication occurs. In addition, inhibition of catalase activity negatively regulates MCMV replication. This study contributes to our understanding of MCMV replication and is helpful for controlling MLN.

\section{Results}

MCMV infection induces the formation of aggregated bodies of peroxisomes in maize leaves

Here, 8-day-old maize seedlings (B73) inoculated with MCMV (pMCM41) showed chlorotic, mottle symptoms and even necrosis at 10 days post-inoculation (dpi), whereas no symptom was observed in control plants mock-inoculated with phosphate buffer (Fig. 1b, c). Our previous research revealed that peroxisomes were highly aggregated in MCMV-infected maize leaves (Jiao et al. 2021). To further determine whether a similar localization pattern of peroxisomes occurs in maize living cells after MCMV infection, we used DsRed-SKL (a peroxisome marker) to visualize the distribution of peroxisomes. Gold particles coated with pGD-DsRed or pGD-DsRed-SKL were bombarded into mock- and MCMV-inoculated maize (B73) leaves. Red fluorescence was observed at $36 \mathrm{~h}$ post-bombardment (hpb). The fluorescence for DsRed alone was distributed in both the

\section{a}
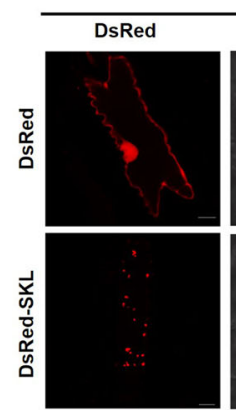

Mock

Merge
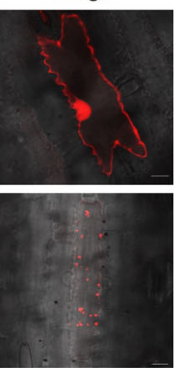

Bright
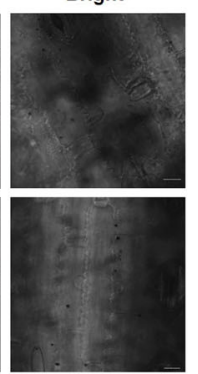

b

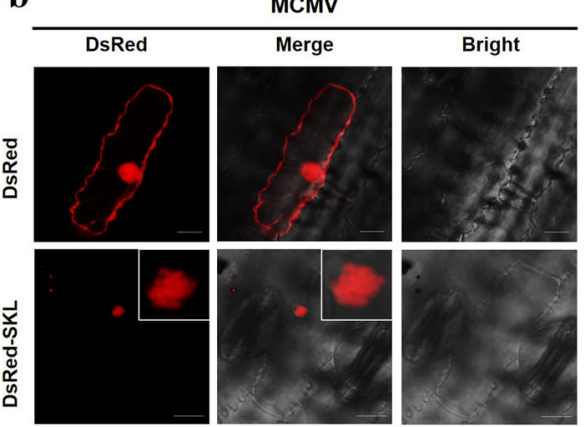

Fig. 2 Peroxisomes relocalize to form aggregated bodies in maize chlorotic mottle virus (MCMV)-infected cells. a, b Particles carrying each of the two plasmids expressing DsRed or DsRed-SKL were bombarded into mock- (a) and MCMV-inoculated (b) maize (B73) leaves. The bombarded leaves were visualized at $36 \mathrm{~h}$ post-bombardment (hpb) by confocal microscopy. Bars, $10 \mu \mathrm{m}$ 
cytoplasm and nucleus (Fig. 2a). Punctate red fluorescence in the cytoplasm was observed when DsRed-SKL was expressed in mock-inoculated maize leaves (Fig. 2a). Intriguingly, red fluorescence from DsRed-SKL was redistributed to aggregated bodies in MCMV-infected maize leaves (Fig. 2b), while the fluorescence for DsRed alone was unchanged after MCMV infection (Fig. 2b). These results indicate that MCMV infection induces maize peroxisomes to form aggregated bodies.

\section{Aggregated peroxisomes serve as the replication sites of MCMV}

It was reported that the aggregated peroxisomes in plants serve as the viral replication sites during infection by tomato bushy stunt virus (TBSV) (McCartney et al. 2005). We presumed that MCMV infection might also cause aggregation of peroxisomes to facilitate its replication in host cells. MCMV encodes two replication proteins, P50 and P111, which are necessary for virus replication (Scheets 2016). To validate whether MCMV RNA synthesis takes place in the aggregated peroxisomes, maize protoplasts were co-transfected with the B2-YN/VP35-YC reporter, GFP-P50 and MCMV in vitro transcripts. Since B2-YN and VP35-YC specifically bind to dsRNA, the reconstituted YFP fluorescence indicates their co-binding to MCMV double-stranded replicative intermediates (Cheng et al. 2015). Confocal results showed that the dsRNA detected by B2-YN and VP35$\mathrm{YC}$ colocalized with the MCMV replication protein P50 (Fig. 3a). No YFP fluorescence signal was observed when maize protoplasts were co-transfected with the B2-YN/ VP35-YC reporter and GFP-P50 in the absence of MCMV (Fig. 3b). Thus, P50 could be used as a marker for identifying the viral replication complex (VRC) of MCMV. We subsequently transfected maize protoplasts with GFP-P50, DsRed-SKL and MCMV in vitro transcripts. As shown in Fig. 3c, GFP-P50 was closely associated with the aggregated peroxisomes (DsRed-SKL). In addition, the P50 protein, expressed alone, targeted and induced maize peroxisomes to form aggregated bodies (Fig. 3d). These results indicate that aggregated peroxisomes serve as the replication sites of MCMV.

\section{ZmCATs are localized in peroxisomes in maize cells}

Although CAT is known to localize primarily in the peroxisomes in many plants, the localization of maize catalases remains largely unknown (Abler and Scandalios 1993). To determine the subcellular localization of ZmCATs, maize protoplasts were co-transfected with pGD-GFP-ZmCAT1/2/3 or pGD-GFP and DsRed-SKL. Fluorescence in maize protoplasts expressing GFP was observed in both the cytoplasm and nucleus (Fig. 4a, line 1), whereas fluorescence from GFP-ZmCATs colocalized with the red fluorescence produced by DsRed-SKL (Fig. 4a, lines 2-4). Similar results were observed in maize epidermal cells (Fig. 4b). A previous study reported that ZmCAT3 might be localized in mitochondria (Willekens et al. 1995). Here, we examined the localization of GFPZmCAT3 in maize protoplasts with mitochondriaspecific dye Mito-Tracker Red, and found that the GFP fluorescent signal did not co-localize with Mito-Tracker Red (Additional file 1: Figure S1). These data indicate that all three $\mathrm{ZmCATs}$ are localized in the peroxisomes in maize cells.

\section{ZmCATs are localized in aggregated peroxisomes in the presence of MCMV}

To explore whether the subcellular localization of ZmCATs is altered during MCMV infection, maize protoplasts were co-transfected with pGD-GFPZmCAT1/2/3 and in vitro transcripts of MCMV. Green fluorescence was observed at $16-24 \mathrm{~h}$ posttransfection (hpt). Interestingly, green fluorescence (GFP-ZmCATs) was observed to form aggregated bodies in the cytoplasm during MCMV infection (Fig. 5a, lanes 2-4), whereas no such aggregated bodies were detected in healthy maize cells (Fig. 5a, lane 1). In addition, similar results were obtained when GFP-ZmCAT1/2/3 were introduced into MCMVinoculated leaf cells by particle bombardment (Fig. 5b). When GFP-ZmCAT1, DsRed-SKL and in vitro transcripts of MCMV were transfected together into maize protoplasts, GFP-ZmCAT1 colocalized with aggregated DsRed-SKL (Fig. 5c). Similar to the results obtained in maize protoplasts, the fluorescence of GFP-ZmCAT1 remained in the aggregated bodies formed by DsRed-SKL in maize epidermal cells (Fig. $5 \mathrm{~d})$. We confirmed the accumulation of MCMV in maize tissues used for bombardment by immunoblotting (Additional file 1: Figure S2). These results indicate that maize catalases are localized in aggregated peroxisomes during MCMV infection. Since MCMV carries out its replication in aggregated peroxisomes, we presumed that catalases play a role in viral replication. To investigate the possible role of catalase in MCMV replication, maize protoplasts were transfected with in vitro transcripts of MCMV and then incubated with $20 \mathrm{mM}$ 3-amino-1, 2, 4-triazole (3-AT, a catalase inhibitor). Northern blot analyses were subsequently conducted with RNA extracts at $18 \mathrm{hpt}$ to quantify the accumulation of MCMV RNA. As shown in Fig. 5e, treatment with 3-AT negatively regulated MCMV RNA accumulation. Catalase can protect cells from the deleterious effects of $\mathrm{H}_{2} \mathrm{O}_{2}$, and the decreased catalase activity may lead to increased accumulation of $\mathrm{H}_{2} \mathrm{O}_{2}$ to produce negative effect on MCMV replication. Importantly, high intracellular ROS production was observed when maize protoplasts 


\section{a}
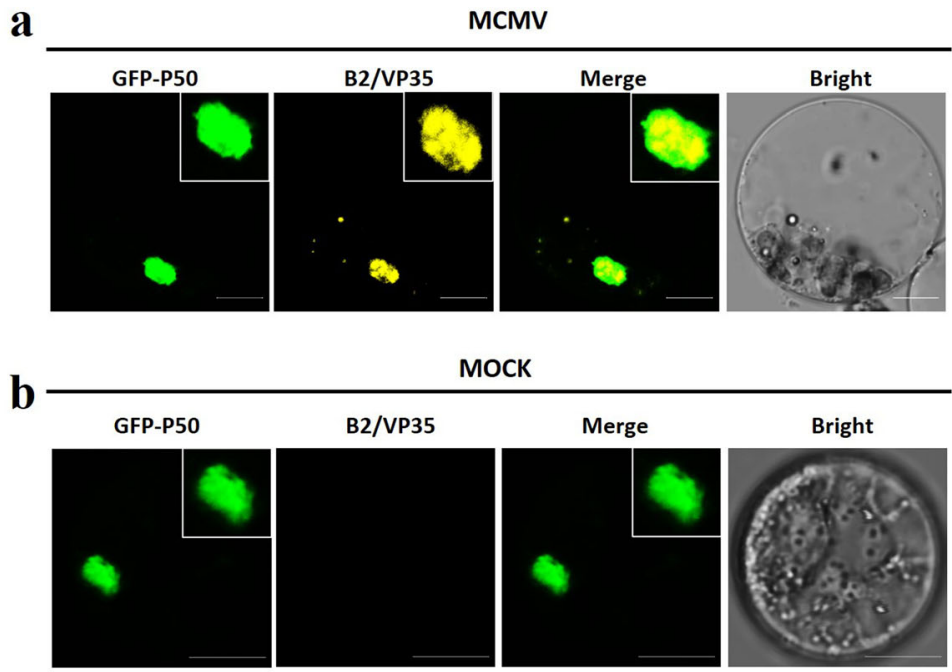

MOCK

c
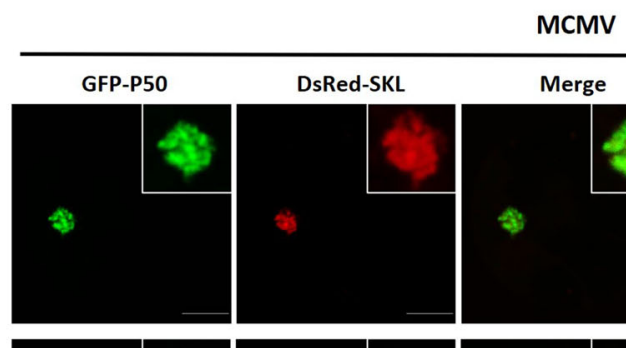

Merge
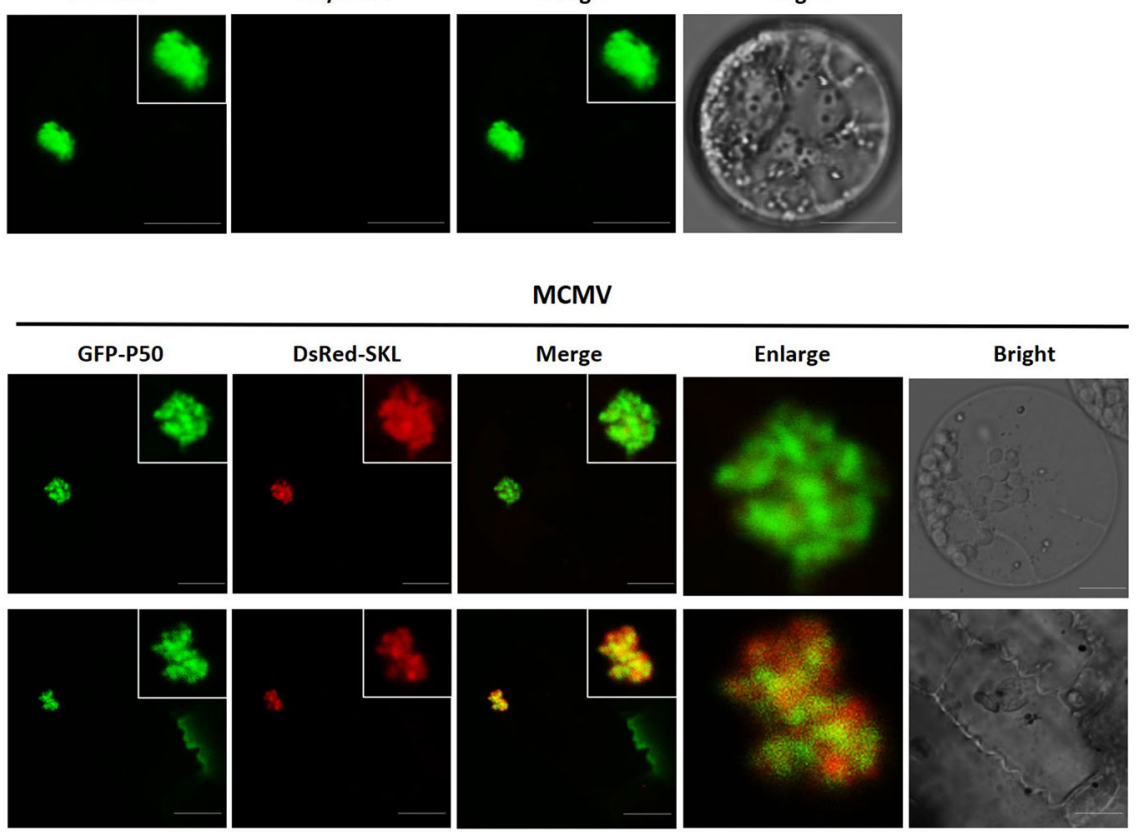

d

MOCK
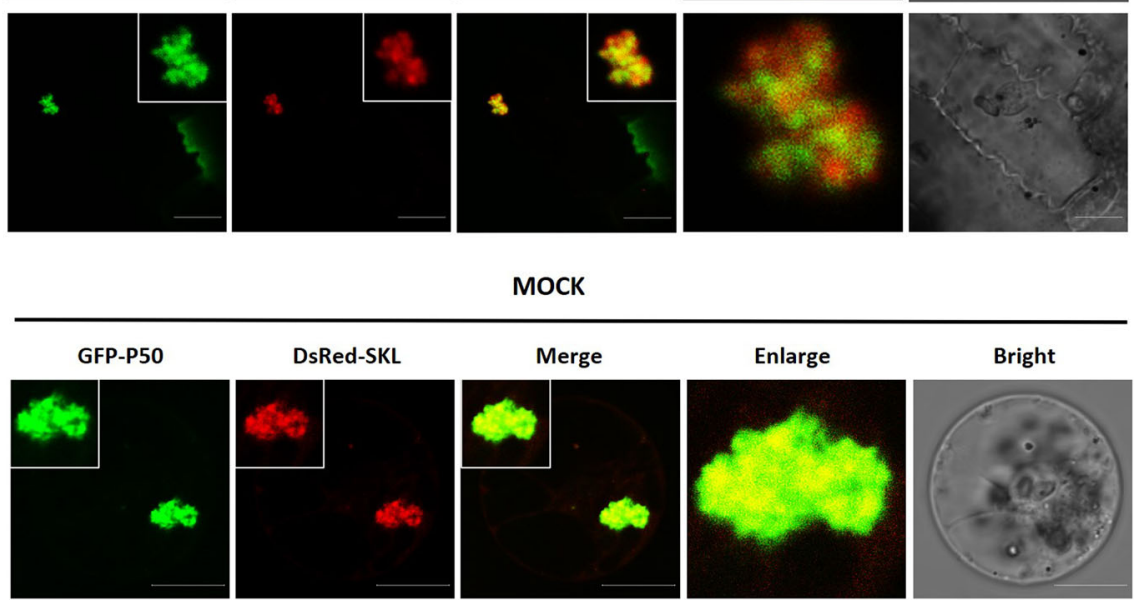

Merge
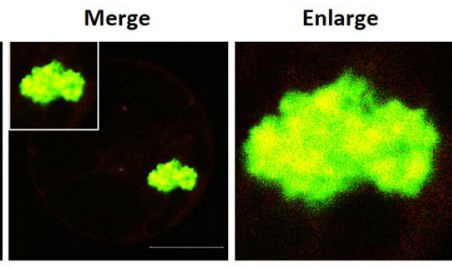

Bright
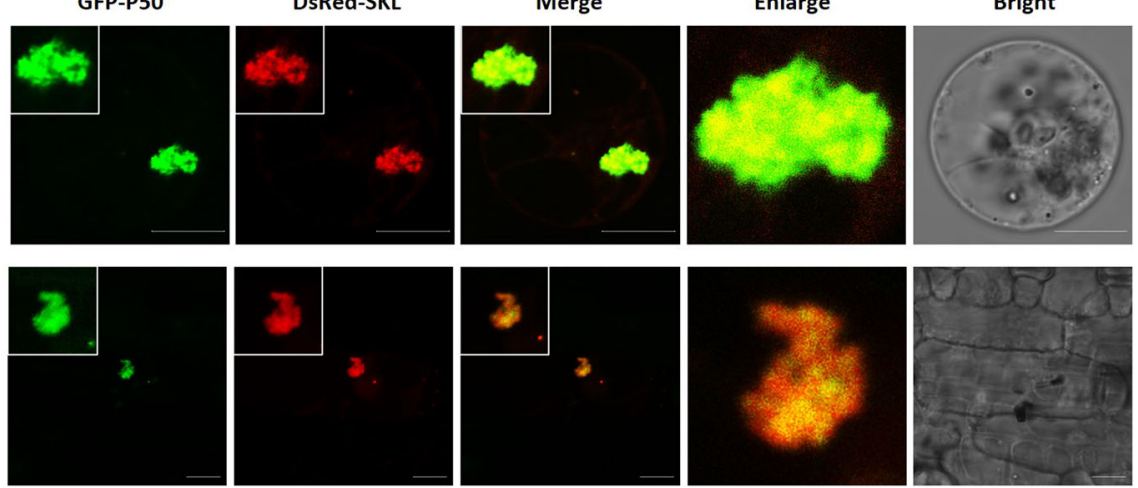

Fig. 3 Aggregated peroxisomes serve as the replication sites of maize chlorotic mottle virus (MCMV). $\mathbf{a}, \mathbf{b}$ Co-localization of dsRNA with the MCMV auxiliary replication protein P50 (GFP-P50) in the presence (a) or absence (b) of MCMV at 3 days post-transfection (dpt). Bars, $10 \mu$ m. C, d Co-localization of MCMV auxiliary replication protein P50 (GFP-P50) with aggregated peroxisomes in the presence (c) or absence (d) of MCMV.

The green/red fluorescence was observed at $24 \mathrm{~h}$ post-transfection (hpt) (protoplasts) and 36 hpb (leaves), respectively. Bars, $10 \mu \mathrm{m}$

were treated with the ROS inducer methyl viologen (MV) (Additional file 1: Figure S3). Thus, maize protoplasts were transfected with in vitro transcripts of
MCMV and then incubated with MV for $18 \mathrm{~h}$. Northern blot analyses indicated that treatment of maize protoplasts with MV led to inhibition of MCMV 
a

DsRed-SKL+
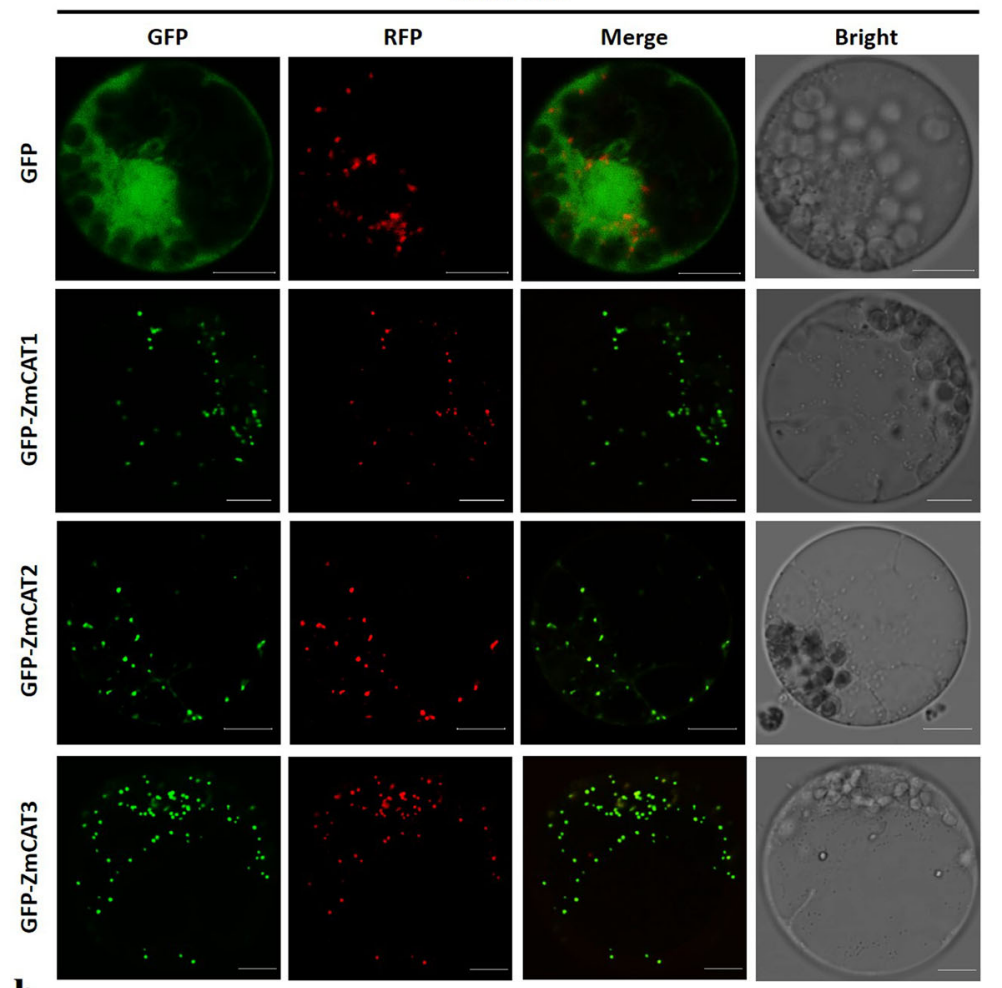

b

DsRed-SKL+
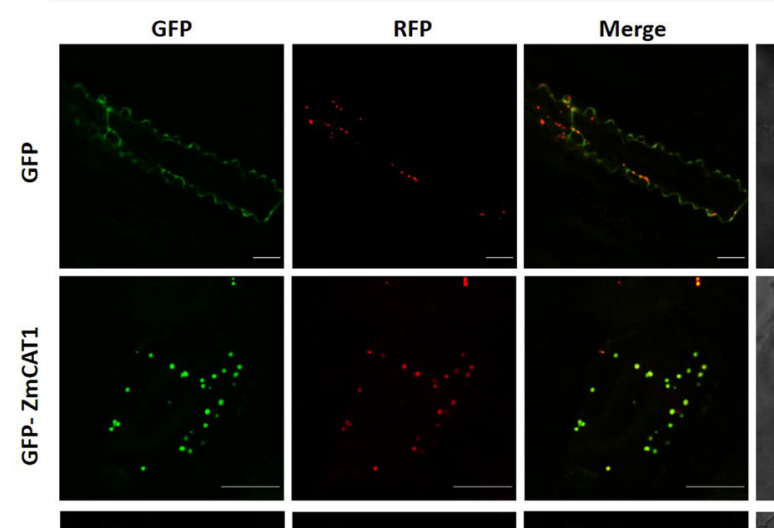

Bright
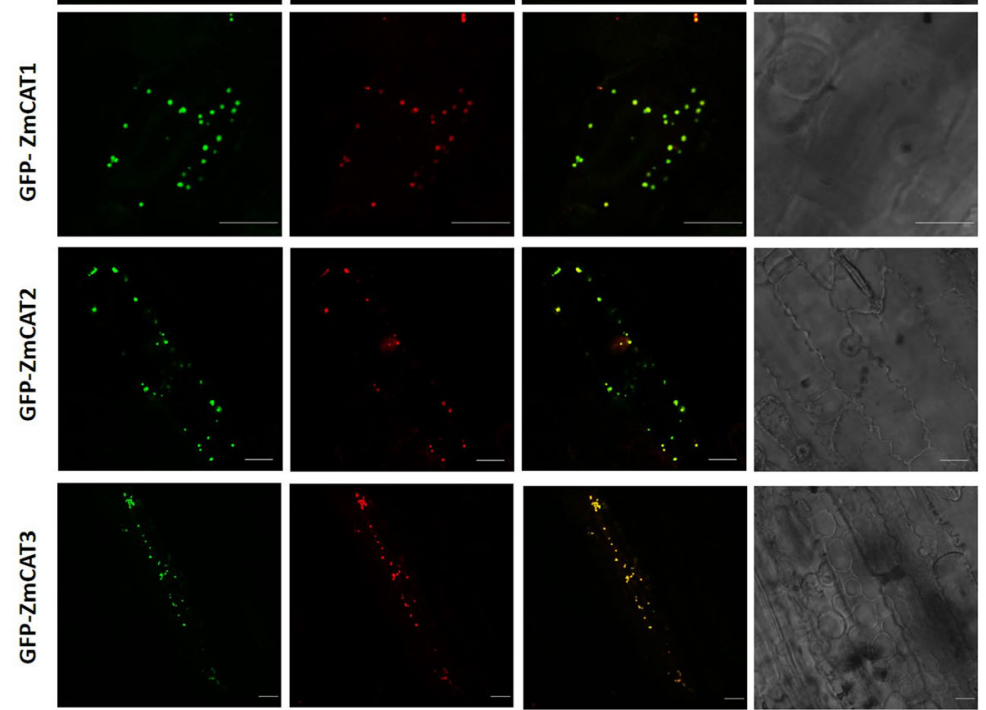

Fig. 4 (See legend on next page.) 
(See figure on previous page.)

Fig. 4 Subcellular localization of ZmCATs in maize cells. a Maize protoplasts were transfected with each plasmid as indicated on the left of each column. DsRed-SKL was used as a peroxisome marker. Red fluorescence signal was captured at $24 \mathrm{hpt}$. Bars, $10 \mu \mathrm{m}$. b Maize leaves were cobombarded with GFP-ZmCAT1/2/3 and DsRed-SKL and the bombarded leaves were examined for the expression of fusion proteins at $36 \mathrm{hpb}$. Bars, $10 \mu \mathrm{m}$

replication (Fig. 5e). Together, these results suggest that maize catalase activity plays an important role in supporting MCMV replication.

\section{Discussion}

P50 and its readthrough protein P111 are the only MCMV proteins required for replication (Scheets 2016), however, the precise replication site of MCMV remains obscure. Using the in vivo double-stranded RNA (dsRNA) labeling system, we showed that the replication of MCMV is associated with peroxisomes (Fig. 3). MCMV infection caused aggregation of peroxisomes (Figs. 2 and 3), with similar situations occurring in infections by some viruses in the family of Tombusviridae (Cook et al. 2019). For instance, tomato bushy stunt virus (TBSV), cucumber necrosis virus (CNV) and cymbidium ringspot virus (CymRSV) use peroxisomes as scaffolds for viral replication factories (Cook et al. 2019). Upon infection, the TBSV p33 protein targets initially from the cytosol to peroxisomes to eventually generate the peroxisome-derived multivesicular bodies (McCartney et al. 2005). During CNV infection, the peroxisome biogenesis is enhanced to facilitate virus replication (Rochon et al. 2014). In addition to support the replication of plant viruses, peroxisomes have long been recognized as key players in human virus infections. For instance, human cytomegalovirus (HCMV) and herpes simplex virus type 1 (HSV-1) change peroxisome morphology to support their replication (Jean Beltran et al. 2018). Additionally, some flaviviruses such as dengue virus (DENV) and West Nile virus (WNV) target their capsid proteins to peroxisome membranes, resulting in a significant decrease in the number of peroxisomes and consequently inhibiting type III interferon expression (peroxisome-mediated immune signaling) (You et al. 2015). On the one hand, studying viral infection provides the opportunity for addressing core questions of peroxisome biology. On the other hand,

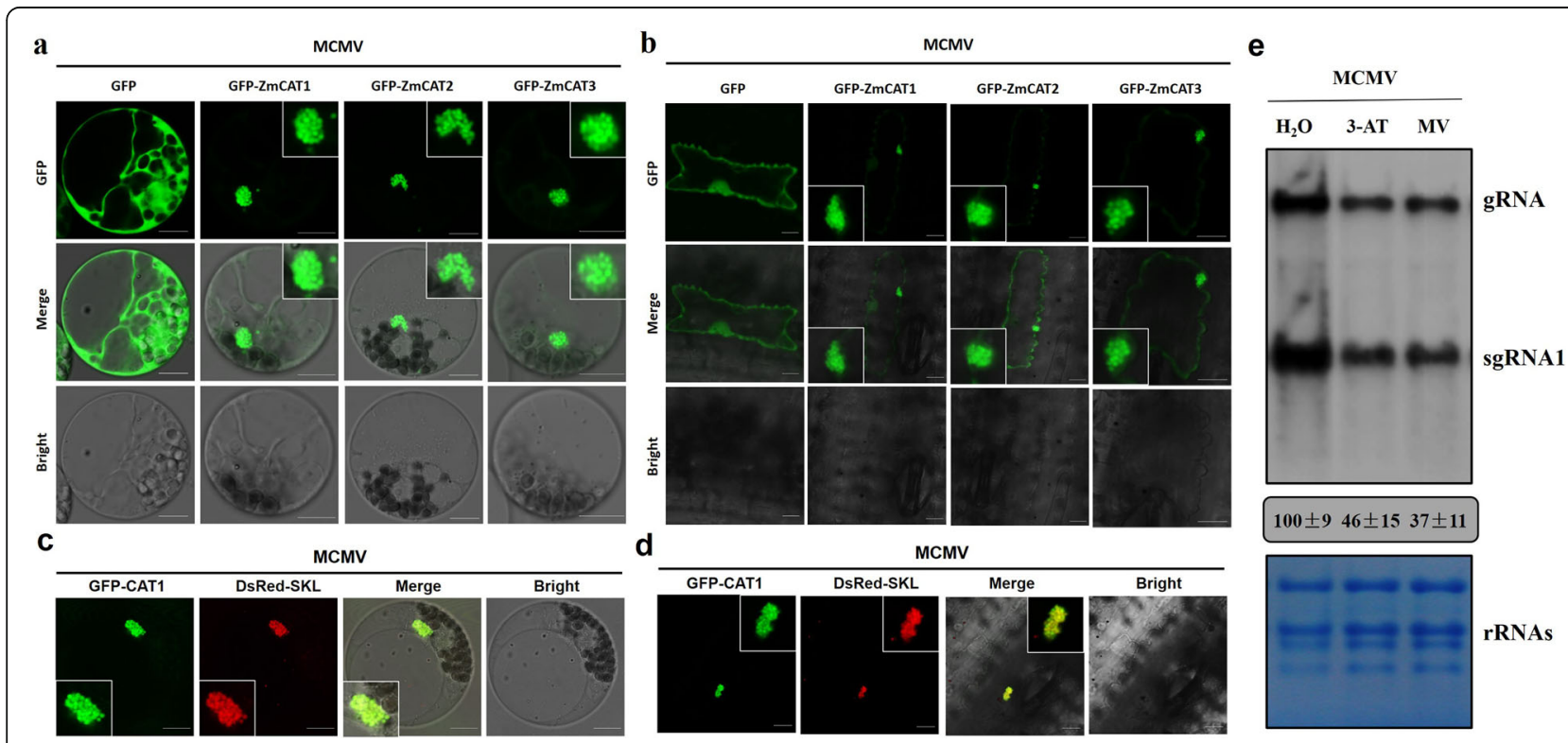

Fig. 5 The peroxisome localization of ZmCATs is required for viral replication of maize chlorotic mottle virus (MCMV). a, b Subcellular localization of ZmCATs in maize protoplasts in the presence of MCMV in vitro transcripts (a) and in MCMV-infected leaves (b). The green/red fluorescence was observed at 24 hpt (a) and 36 hpb (b), respectively. Bars, $10 \mu \mathrm{m}$. c, d GFP-ZmCAT1 co-expressed with DsRed-tagged peroxisome marker SKL in MCMV-infected maize protoplasts (c) and MCMV-inoculated maize leaves (d). The green/red fluorescence was observed at $24 \mathrm{hpt}$ (c) and $36 \mathrm{hpb}$ (d), respectively. Bars, $10 \mu \mathrm{m}$. e Protoplasts were inoculated with MCMV in vitro transcripts and incubated at $25^{\circ} \mathrm{C}$ for $18 \mathrm{~h}$ in the presence of 20 mM 3-AT (3-amino-1, 2, 4-triazole) or $10 \mu \mathrm{M}$ MV (methyl viologen). The accumulation levels of MCMV genomic RNA were determined by Northern blot and visualized with the IMAGE J software. The numbers shown below the gel indicate the ratio of MCMV genomic RNA (top band) accumulation level in 3-AT/MV-treated maize protoplasts to that in the $\mathrm{H}_{2} \mathrm{O}$-treated control maize protoplasts (presented as 100). Relative genomic RNA accumulation was calculated from maize protoplast Northern blot data for three separate inoculation experiments and represents mean \pm standard error 
elucidating the processes underlying peroxisome biology may also provide strategies to selectively inhibit peroxisome-mediated functions required for viral infection.

In this study, we determined that all the three maize catalases are localized in peroxisomes (Fig. 4). Both ZmCAT1 and ZmCAT2 contain a tripeptide SRL (while ZmCAT3 contains a TRL) with a peroxisomal targeting signal in the C-terminal. Previous study reported that ZmCAT3 co-isolated with the mitochondrial fraction of mesophyll cells (Scandalios et al. 1980). In addition, proteomic analysis of highly purified mitochondria from Arabidopsis cells also identified AtCAT2 and AtCAT3 (Heazlewood et al. 2004). There has been no demonstration of catalase import into angiosperm mitochondria. These findings may indicate a progressive decline throughout the mitochondrial purification procedure. Thus, it is possible that contamination may account for previous reports on catalase activity in mitochondria. However, peroxisomal catalase can change the localization to other organelles under some conditions. For instance, yeast catalase was co-localized to mitochondria in a manner dependent on nutritional conditions (Petrova et al. 2004; Mhamdi et al. 2010). Therefore, dual peroxisomal/mitochondrial targeting of catalases cannot be ruled out. In this study, the catalase activity is required for MCMV replication because treatment with catalase inhibitor 3-AT reduced MCMV replication (Fig. 5e). Since the accumulation of $\mathrm{H}_{2} \mathrm{O}_{2}$ can impede virus replication, it is likely that catalases are needed to maintain a specific site for assembling viral replication complex (VRC) (Fig. 5e). This may also explain why the localization of ZmCATs to peroxisome is not altered in the presence of MCMV.

CAT is not only a strong antioxidant enzyme in scavenging $\mathrm{H}_{2} \mathrm{O}_{2}$, but also plays critical roles in plant responses to various stresses. It is reported that a rice salt tolerance receptor-like cytoplasmic kinase 1 (STRK1) anchors and interacts with OsCatC at the plasma membrane (Zhou et al. 2018). The OsCatC is phosphorylated and activated by STRK1, thereby regulating $\mathrm{H}_{2} \mathrm{O}_{2}$ homeostasis and improving salt tolerance in rice (Zhou et al. 2018). Recently, evidence has emerged that AtCAT2 regulates leaf senescence in Arabidopsis (Guo et al. 2017). The transcription factor WRKY75 as a positive regulator of leaf senescence suppresses $\mathrm{H}_{2} \mathrm{O}_{2}$ scavenging partly by repressing the transcription of AtCAT2 (Guo et al. 2017). Increasing evidences show that catalase regulates plant resistance to diverse pathogens. For instance, biotrophic-pathogen-induced salicylic acid (SA) accumulation dampens both auxin and jasmonic acid (JA) synthesis by inhibiting AtCAT2 activity in Arabidopsis (Yuan et al. 2017). Suppression of AtCAT2 by SA results in high levels of $\mathrm{H}_{2} \mathrm{O}_{2}$, leading to sulfenylation of tryptophan synthetase $\mathrm{b}$ subunit 1 , thus depleting the auxin biosynthetic precursor tryptophan (Yuan et al. 2017). AtCAT2 promotes acyl-CoA oxidase 2 (ACX2) and ACX3 activity to increase JA accumulation (Yuan et al. 2017). In addition, the pathogenic oomycete Phytophthora sojae secretes two cytoplasmic effectors, PsCRN63 and PsCRN115, to recruit NbCAT1 into nucleus (Zhang et al. 2015). Furthermore, these two effectors manipulate plant programmed cell death (PCD) through interfering with catalases and eventually perturbing $\mathrm{H}_{2} \mathrm{O}_{2}$ homeostasis (Zhang et al. 2015).

The effects of interactions between CATs and viruses varied in different host-pathogen systems. For instance, helper component proteinase (HC-Pro) encoded by chilli veinal mottle virus (ChiVMV) directly interacts with CAT1 and CAT3 of Nicotiana tabacum in the cytoplasm to facilitate viral infection (Yang et al. 2020). Neither CAT1 nor CAT3 affects the RNA silencing suppression activity of HC-Pro (Yang et al. 2020). However, the interaction between CMV-HL 2b and AtCAT3 significantly inactivates the RNA silencing suppression activity of CMV-HL 2b (Inaba et al. 2011). Intriguingly, some virus-induced necrosis are consequences of direct protein-protein interactions between viral pathogenicity determinants and host catalases. In our previous study, we reported that MCMV P31 interacts with maize catalases $1 / 3$ to inhibit their catalase activities, and subsequently attenuate SA-mediated defense (Jiao et al. 2021). Thus, systemic necrosis is observed in upper noninoculated leaves (Jiao et al. 2021). Similarly, tomato leaf curl Palampur virus AV2 protein promotes systemic necrosis in Nicotiana benthamiana plants by interacting with host CAT2 (Roshan et al. 2018). In this study, we revealed that catalase activity positively regulates MCMV replication especially under high-ROS condition (Fig. 5e). Maize catalases have been identified to regulate several processes in MCMV infection. The regulatory mechanisms underlying the ROS metabolism and MCMV infection need to be further investigated.

\section{Conclusions}

MCMV is the emerging virus that drives MLN expansion. Elucidating the molecular mechanisms underlying MCMV pathogenesis will be conducive to controlling this devastating disease. In this study, we revealed that MCMV infection induced maize peroxisomes to form aggregated bodies, which served as viral replication sites. The three maize catalases were shown to localize in peroxisomes in the absence and presence of MCMV RNA. In addition, inhibiting catalase activity negatively regulated MCMV replication. The results are conducive to elucidating the replication mechanisms of MCMV, and also to understanding the molecular interaction between MCMV and host maize. 


\section{Methods}

\section{Plant growth conditions and virus inoculation}

Maize seedlings (inbred line B73) were grown in a growth chamber $\left(24{ }^{\circ} \mathrm{C}\right.$ day $/ 22^{\circ} \mathrm{C}$ night, $16 \mathrm{~h}$ light $/ 8 \mathrm{~h}$ dark) for virus inoculation and analyses.

MCMV was prepared from the full-length cDNA clone (pMCM41) (Scheets et al. 1993). Crude extracts were prepared by homogenizing the MCMV-infected maize (B73) leaf tissues in $0.01 \mathrm{M}$ phosphate buffer [0.01 M $\left.\mathrm{KH}_{2} \mathrm{PO}_{4}: 0.01 \mathrm{M} \mathrm{Na}_{2} \mathrm{HPO}_{4}=49: 51(\mathrm{v} / \mathrm{v}), \mathrm{pH} 7.0\right]$ at $1: 10$ $(\mathrm{w} / \mathrm{v})$ ratio.

\section{Plasmid construction}

The coding sequences of $Z m C A T 1$ (GenBank accession no. NM_001254879.2), ZmCAT2 (NM_001111840.2) and ZmCAT3 (NM_001363892.1) were amplified individually from maize by reverse transcription-PCR (RTPCR). For transient expression assays, constructs were based on a pGD vector (Goodin et al. 2002). All constructs were confirmed by sequencing. Primers used in this study are listed in Additional file 2: Table S1.

\section{Preparation of MCMV RNA transcripts}

RNA transcripts of MCMV (pMCM41) were prepared as described previously (Scheets et al. 1993; Zhu et al. 2014). Plasmids (pMCM41) linearized with Sma I were used for in vitro transcription of RNAs. The MCMV RNA transcripts were synthesized using a T7 RiboMAX ${ }^{\text {тм }}$ Express Large Scale RNA Production System (Promaga, Madison, WI, USA; Cat: P1320). Then the RNA transcripts were treated with RQ1 RNase-free DNase (Promega) followed by extraction with phenol/chloroform and then only chloroform. Next, the resulting supernatant was mixed with $3 \mathrm{M} \mathrm{NaAc}(\mathrm{pH} 5.2)(10: 1, \mathrm{v} / \mathrm{v})$ and ethanol $(1: 2, \mathrm{v} / \mathrm{v})$ followed by precipitation at $-80{ }^{\circ} \mathrm{C}$ for $20 \mathrm{~min}$. The RNA transcripts were pelleted at 13000 $g$ for $10 \mathrm{~min}$ at $4{ }^{\circ} \mathrm{C}$ and the pellet was washed twice with ice-cold $75 \%$ ethanol $(1 \mathrm{~mL})$. The pellet was then resuspended in RNase-free double-distilled (dd) $\mathrm{H}_{2} \mathrm{O}$.

\section{Isolation and transfection of maize protoplasts}

Isolation and transfection of maize protoplasts were conducted as described previously (Sheen 1991; Zhu et al. 2014). For catalase inhibitor treatment assay, maize protoplasts were transfected with in vitro transcripts of MCMV $(1 \mu \mathrm{g})$ and incubated with $20 \mathrm{mM}$ 3-amino-1, 2, 4-triazole (3-AT; Sigma-Aldrich) at $25^{\circ} \mathrm{C}$ under light for $18 \mathrm{~h}$. For the ROS inducer methyl viologen (MV) treatment assay, maize protoplasts were transfected with in vitro transcripts of MCMV $(1 \mu \mathrm{g})$ and incubated with $10 \mu \mathrm{M}$ MV (Sigma-Aldrich) at $25^{\circ} \mathrm{C}$ under light for $18 \mathrm{~h}$. Each experiment was repeated at least three times using different batches of maize protoplasts.

\section{Particle bombardment}

Particle bombardment was performed as described previously (Kirienko et al. 2012; Chen et al. 2017), with slight modifications. One-month-old maize plants (B73) were inoculated with MCMV or phosphate buffer (mock). At 2 weeks post-inoculation, the maize tissue samples were collected and prepared before use. Approximately $8 \mu \mathrm{L}(60 \mu \mathrm{g} / \mu \mathrm{L})$ of the gold particle stock solution was mixed with $5 \mu \mathrm{g}$ plasmid DNA, $20 \mu \mathrm{L}$ of $0.1 \mathrm{M}$ spermidine solution and $10 \mu \mathrm{L}$ of $2.5 \mathrm{M} \mathrm{CaCl}_{2}$ solution in an Eppendorf tube. The mixture was vortexed at a low speed for $3 \mathrm{~min}$ and then pelleted at 10,000 $\mathrm{g}$ for $20 \mathrm{~s}$. After two washes in $1 \mathrm{~mL}$ of $100 \%$ ethanol, the pellets of gold-plasmid DNA particles were resuspended with $10 \mu \mathrm{L}$ of $100 \%$ ethanol solution and transferred to microcarriers (Bio-Rad). Vacuum pressure within the chamber was allowed to reach 27 to 28 inches of mercury prior to firing (PDS-1000/He system, Bio-Rad). The bombarded leaves were allowed to recover at $25^{\circ} \mathrm{C}$ in the dark and examined for the expression of fusion proteins at $36 \mathrm{hpb}$.

\section{dsRNA binding-dependent fluorescence complementation (dRBFC)}

Mazie protoplasts were prepared and transfected with a previously reported B2-YN/VP35-YC reporter (Cheng et al. 2015) and GFP-P50. At $3 \mathrm{dpt}$, the protoplasts were harvested for imaging with a confocal microscope.

\section{Detection of ROS production}

For ROS staining assays with CM- $\mathrm{H}_{2}$ DCFDA [5-(and-6)chloromethyl-2',7' -dichlorodihydrofluorescein diacetate; Invitrogen], maize protoplasts were incubated with the ROS inducer MV for $18 \mathrm{~h}$. Then the maize protoplasts were incubated for $15 \mathrm{~min}$ at room temperature in $1 \mu \mathrm{M}$ $\mathrm{CM}-\mathrm{H}_{2} \mathrm{DCFDA}$. Fluorescence was observed by using a laser scanning confocal microscope (Leica, SP8).

\section{Confocal microscopic observation}

For subcellular localization and dRBFC assays, samples were observed under a laser scanning confocal microscope (Leica, SP8). The fluorescence of GFP and YFP was both excited at $488 \mathrm{~nm}$, then captured at 495-545 $\mathrm{nm}$ and $520-580 \mathrm{~nm}$, respectively. The fluorescence of DsRed were excited by wavelength of $552 \mathrm{~nm}$ and detected at 562 to $620 \mathrm{~nm}$. For co-localization analysis, each of the channel was scanned and imaged sequentially. The images were processed using Adobe Photoshop (Adobe, San Jose, CA, USA).

\section{Immunoblot analysis}

The protein extraction and immunoblot assays were performed as described previously (Cao et al. 2012). MCMV coat protein $(\mathrm{CP})$ antibody was kindly provided by Profs. 


\section{Xueping Zhou and Jianxiang Wu (Zhejiang University) and used at a dilution of 1: 10000 .}

\begin{abstract}
Abbreviations
ACX: Acyl-CoA oxidase; 3-AT: 3-amino-1, 2, 4-triazole; CAT: Catalase; ChivMV: Chilli veinal mottle virus; CMV: Cucumber mosaic virus; CP: Coat protein; DENV: Dengue virus; dRBFC: dsRNA binding-dependent fluorescence complementation; GFP: Green fluorescent protein; HCMV: Human cytomegalovirus; HC-Pro: Helper component-proteinase; $\mathrm{H}_{2} \mathrm{O}_{2}$ : Hydrogen peroxide; HSV-1: Herpes simplex virus type 1; JA: Jasmonic acid; JGMV: Johnsongrass mosaic virus; MCMV: Maize chlorotic mottle virus; MDMV: Maize dwarf mosaic virus; MLN: Maize lethal necrosis; MV: Methyl viologen; $\mathrm{O}_{2}^{-}$: Superoxide anion radical; $\mathrm{OH}$ : Hydroxyl radical;

PCD: Programmed cell death; ROS: Reactive oxygen species; SA: Salicylic acid; SCMV: Sugarcane mosaic virus; STRK1: Salt tolerance receptor-like cytoplasmic kinase 1; TBSV: Tomato bushy stunt virus; VRC: Virus replication complex; WNV: West Nile virus; WSMV: Wheat streak mosaic virus; YFP: Yellow fluorescent protein
\end{abstract}

\section{Supplementary Information}

The online version contains supplementary material available at https://doi. org/10.1186/s42483-021-00094-x.

Additional file 1: Figure S1. Subcellular localization of ZmCAT3 in maize protoplasts. Mazie protoplasts were transfected with pGD-GFPZmCAT3 for $18 \mathrm{~h}$. Mito-Tracker Red was retained in the mitochondria before photographing. Bars, $10 \mu \mathrm{m}$. Figure S2. The accumulation of maize chlorotic mottle virus (MCMV) coat protein (CP) in tissues used for bombardment. Equal amounts of total proteins extracted from MCMVinfected maize (B73) leaves (positive control), phosphate buffer (mock)- or MCMV-inoculated maize (B73) tissues (to be used for bombardment, i.e. pGD-GFP-ZmCAT1/2/3, etc.) were used for immunoblot analysis with MCMV CP antibody. Figure $\mathbf{S 3}$ The $\mathrm{H}_{2}$ DCFDA-stained maize protoplasts in the presence of methyl viologen (MV). a, b Maize protoplasts were treated with $\mathrm{dd}_{2} \mathrm{O}$ (control, a) or $10 \mu \mathrm{M}$ ROS inducer MV (b) for $18 \mathrm{~h}$. The maize protoplasts were incubated for $15 \mathrm{~min}$ at room temperature in $1 \mu \mathrm{M} C \mathrm{C}-\mathrm{H}_{2} \mathrm{DCFDA}$. Fluorescence was observed by using a laser scanning confocal microscope. Bars, $100 \mu \mathrm{m}$.

Additional file 2: Table S1. Primers used for construction of plasmids and the probes for Northern blotting of MCMV genomic RNAs.

\section{Acknowledgements}

We thank Dr. Kay Scheets (Oklahoma State University) for providing the fulllength cDNA clone of MCMV (pMCM41), Dr. Andrew Jackson (University of California, Berkeley) for providing the pGD vector, Dr. Aiming Wang (Agriculture and Agri-Food Canada) for providing the dRBFC plasmids. We are indebted to Drs. Xueping Zhou and Jianxiang Wu (Zhejiang University) for providing the DsRed-SKL vector and MCMV CP antibody. We thank Drs. Na Jiang and Linlu Qi (China Agricultural University) for confocal microscopy assistance.

\section{Authors' contributions}

ZJ and ZF designed the research. ZJ performed most of the experiments and prepared the data. JW, YT, SW, XS, SL and WM helped with the subcellular localization assays. ZJ and ZF wrote the manuscript. All authors read and approved the final manuscript.

\section{Funding}

This work was supported by grants from the Ministry of Science and Technology (2016YFD0300710), the National Natural Science Foundation of China (no. 31571980), the Ministry of Education (the 111 Project B13006), and State Key Laboratory of Agrobiotechnology (2019SKLAB6-19).

\section{Availability of data and materials}

Not applicable.

\section{Declarations}

Ethics approval and consent to participate

Not applicable.

\section{Consent for publication}

Not applicable.

\section{Competing interests}

The authors declare that they have no competing interests.

Received: 26 April 2021 Accepted: 10 July 2021

Published online: 31 July 2021

\section{References}

Abler ML, Scandalios JG. Isolation and characterization of a genomic sequence encoding the maize Cat3 catalase gene. Plant Mol Biol. 1993;22(6):1031-8. https://doi.org/10.1007/BF00028975.

Anjum NA, Sharma P, Gill SS, Hasanuzzaman M, Khan EA, Kachhap K, et al. Catalase and ascorbate peroxidase-representative $\mathrm{H}_{2} \mathrm{O}_{2}$-detoxifying heme enzymes in plants. Environ Sci Pollut Res. 2016;23(19):19002-29. https://doi. org/10.1007/s11356-016-7309-6.

Brown LA, Baker A. Shuttles and cycles: transport of proteins into the peroxisome matrix (review). Mol Membr Biol. 2008;25(5):363-75. https://doi.org/10.1080/ 09687680802130583.

Cao Y, Shi Y, Li Y, Cheng Y, Zhou T, Fan Z. Possible involvement of maize Rop1 in the defence responses of plants to viral infection. Mol Plant Pathol. 2012; 13(7):732-43. https://doi.org/10.1111/j.1364-3703.2011.00782.x.

Carino EJ, Scheets K, Miller WA. The RNA of maize chlorotic mottle virus, an obligatory component of maize lethal necrosis disease, is translated via a variant panicum mosaic virus-like cap-independent translation element. J Virol. 2020;94:e01005-20.

Chelikani P, Fita I, Loewen PC. Diversity of structures and properties among catalases. Cell Mol Life Sci. 2004;61(2):192-208. https://doi.org/10.1007/s0001 8-003-3206-5.

Chen L, Yan Z, Xia Z, Cheng Y, Jiao Z, Sun B, et al. A violaxanthin deepoxidase interacts with a viral suppressor of RNA silencing to inhibit virus amplification. Plant Physiol. 2017;175(4):1774-94. https://doi.org/10.1104/pp.1 7.00638 .

Cheng X, Deng P, Cui H, Wang A. Visualizing double-stranded RNA distribution and dynamics in living cells by dsRNA binding-dependent fluorescence complementation. Virology. 2015;485:439-51. https://doi.org/10.1016/j.virol.2 015.08.023.

Cook KC, Moreno JA, Jean Beltran PM, Cristea IM. Peroxisome plasticity at the virus-host interface. Trends Microbiol. 2019;27(11):906-14. https://doi.org/10.1 016/j.tim.2019.06.006.

Dempsey DA, Shah J, Klessig DF. Salicylic acid and disease resistance in plants. Crit Rev Plant Sci. 1999;18(4):547-75. https://doi.org/10.1080/073526899913 09397.

Goldberg KB, Brakke MK. Concentration of maize chlorotic mottle virus increased in mixed infections with maize dwarf mosaic virus, strain B. Phytopathology. 1987;77(2):162-7. https://doi.org/10.1094/Phyto-77-162.

Goodin MM, Dietzgen RG, Schichnes D, Ruzin S, Jackson AO. pGD vectors: versatile tools for the expression of green and red fluorescent protein fusions in agroinfiltrated plant leaves. Plant J. 2002; 31(3):375-83. https://doi.org/10.1 046/j.1365-313x.2002.01360.x.

Guan L, Polidoros AN, Scandalios JG. Isolation, characterization and expression of the maize Cat2 catalase gene. Plant Mol Biol. 1996;30(5):913-24. https://doi. org/10.1007/BF00020803.

Guan L, Scandalios JG. Characterization of the catalase antioxidant defense gene Cat1 of maize, and its developmentally regulated expression in transgenic tobacco. Plant J. 1993;3(4):527-36. https://doi.org/10.1046/j.1365-313X.1993.03 040527.x.

Guo P, Li Z, Huang P, Li B, Fang S, Chu J, et al. A tripartite amplification loop involving the transcription factor WRKY75, salicylic acid, and reactive oxygen species accelerates leaf senescence. Plant Cell. 2017;29(11):2854-70. https:// doi.org/10.1105/tpc.17.00438.

Heazlewood JL, Tonti-Filippini JS, Gout AM, Day DA, Whelan J, Millar AH. Experimental analysis of the Arabidopsis mitochondrial proteome highlights signaling and regulatory components, provides assessment of targeting 
prediction programs, and indicates plant-specific mitochondrial proteins. Plant Cell. 2004;16(1):241-56. https://doi.org/10.1105/tpc.016055.

Inaba J, Kim BM, Shimura H, Masuta C. Virus-induced necrosis is a consequence of direct protein-protein interaction between a viral RNA-silencing suppressor and a host catalase. Plant Physiol. 2011;156(4):2026-36. https:// doi.org/10.1104/pp.111.180042.

Jean Beltran PM, Cook KC, Hashimoto Y, Galitzine C, Murray LA, Vitek O, et al. Infection-induced peroxisome biogenesis is a metabolic strategy for herpesvirus replication. Cell Host Microbe. 2018;24(4):526-41. https://doi. org/10.1016/j.chom.2018.09.002

Jiao Z, Tian Y, Cao Y, Wang J, Zhan B, Zhao Z, et al. A novel pathogenicity determinant hijacks maize catalase 1 to enhance viral multiplication and infection. New Phytol. 2021;230(3):1126-41. https://doi.org/10.1111/nph.17206.

Kirienko DR, Luo A, Sylvester AW. Reliable transient transformation of intact maize leaf cells for functional genomics and experimental study. Plant Physiol. 2012; 159(4):1309-18. https://doi.org/10.1104/pp.112.199737.

Lamb C, Dixon RA. The oxidative burst in plant disease resistance. Annu Rev Plant Physiol Plant Mol Biol. 1997;48(1):251-75. https://doi.org/10.1146/a nnurev.arplant.48.1.251

Lehmann S, Serrano M, L'Haridon F, Tjamos SE, Metraux JP. Reactive oxygen species and plant resistance to fungal pathogens. Phytochemistry. 2015;112: 54-62. https://doi.org/10.1016/j.phytochem.2014.08.027.

Magbanua ZV, De Moraes CM, Brooks TD, Williams WP, Luthe DS. Is catalase activity one of the factors associated with maize resistance to Aspergillus flavus? Mol Plant-Microbe Interact. 2007;20(6):697-706. https://doi.org/10.1 094/MPMI-20-6-0697.

Mathioudakis MM, Veiga RS, Canto T, Medina V, Mossialos D, Makris AM, et al. Pepino mosaic virus triple gene block protein 1 (TGBp1) interacts with and increases tomato catalase 1 activity to enhance virus accumulation. Mol Plant Pathol. 2013;14(6):589-601. https://doi.org/10.1111/mpp.12034.

McCartney AW, Greenwood JS, Fabian MR, White KA, Mullen RT. Localization of the tomato bushy stunt virus replication protein p33 reveals a peroxisometo-endoplasmic reticulum sorting pathway. Plant Cell. 2005;17(12):3513-31. https://doi.org/10.1105/tpc.105.036350.

Mellersh DG, Foulds IV, Higgins VJ, Heath MC. $\mathrm{H}_{2} \mathrm{O}_{2}$ plays different roles in determining penetration failure in three diverse plant-fungal interactions. Plant J. 2002;29(3):257-68. https://doi.org/10.1046/j.0960-7412.2001.01215.x.

Mhamdi A, Queval G, Chaouch S, Vanderauwera S, van Breusegem F, Noctor G. Catalase function in plants: a focus on Arabidopsis mutants as stress-mimic models. J Exp Bot. 2010;15:4197-220.

Murota K, Shimura H, Takeshita M, Masuta C. Interaction between cucumber mosaic virus $2 \mathrm{~b}$ protein and plant catalase induces a specific necrosis in association with proteasome activity. Plant Cell Rep. 2017;36(1):37-47. https:// doi.org/10.1007/s00299-016-2055-2.

Nutter RC, Scheets K, Panganiban LC, Lommel SA. The complete nucleotidesequence of the maize chlorotic mottle virus genome. Nucleic Acids Res. 1989;17(8):3163-77. https://doi.org/10.1093/nar/17.8.3163.

Petrova VY, Drescher D, Kujumdzieva AV, Schmitt MJ. Dual targeting of yeast catalase A to peroxisomes and mitochondria. Biochem J. 2004;380(2):393400. https://doi.org/10.1042/bj20040042.

Redinbaugh MG, Sabre M, Scandalios JG. The distribution of catalase activity, isozyme protein, and transcript in the tissues of the developing maize seedling. Plant Physiol. 1990;92(2):375-80. https://doi.org/10.1104/pp.92.2.375.

Redinbaugh MG, Stewart LR. Maize lethal necrosis: an emerging, synergistic viral disease. Annu Rev Virol. 2018;5(1):301-22. https://doi.org/10.1146/annurevvirology-092917-043413

Rochon D, Singh B, Reade R, Theilmann J, Ghoshal K, Alam SB, et al. The p33 auxiliary replicase protein of cucumber necrosis virus targets peroxisomes and infection induces de novo peroxisome formation from the endoplasmic reticulum. Virology. 2014;452:133-42.

Roshan P, Kulshreshtha A, Kumar S, Purohit R, Hallan V. AV2 protein of tomato leaf curl Palampur virus promotes systemic necrosis in Nicotiana benthamiana and interacts with host Catalase2. Sci Rep. 2018;8(1):1273. https://doi.org/10.1038/s41598-018-19292-3.

Roupakias DG, Mcmillin DE, Scandalios JG. Chromosomal location of the catalase structural genes in Zea mays using B-A translocations. Theor Appl Genet. 1980;58(5):211-8. https://doi.org/10.1007/BF00288439.

Scandalios JG, Tong WF, Roupakias DG. Cat3, a third gene locus coding for a tissue-specific catalase in maize: genetics, intracellular location, and some biochemical properties. Mol Gen Genet. 1980;179(1):33-41. https://doi.org/1 $0.1007 /$ BF00268443
Scandalios JG, Tsaftaris AS, Chandlee JM, Skadsen RW. Expression of the developmentally regulated catalase (cat) genes in maize. Dev Genet. 1984;4: 281-93.

Scheets K. Maize chlorotic mottle machlomovirus and wheat streak mosaic rymovirus concentrations increase in the synergistic disease corn lethal necrosis. Virology. 1998;242(1):28-38. https://doi.org/10.1006/viro.1997.8989.

Scheets K. Maize chlorotic mottle machlomovirus expresses its coat protein from a 1.47-kb subgenomic RNA and makes a 0.34-kb subgenomic RNA. Virology. 2000;267(1):90-101. https://doi.org/10.1006/viro.1999.0107.

Scheets K. Analysis of gene functions in maize chlorotic mottle virus. Virus Res. 2016;222:71-9. https://doi.org/10.1016/j.virusres.2016.04.024

Scheets K, Khosravifar R, Nutter RC. Transcripts of a maize chlorotic mottle virus cDNA clone replicate in maize protoplasts and infect maize plants. Virology. 1993;193(2):1006-9. https://doi.org/10.1006/viro.1993.1216.

Schippers JH, Nguyen HM, Lu D, Schmidt R, Mueller-Roeber B. ROS homeostasis during development: an evolutionary conserved strategy. Cell Mol Life Sci. 2012;69(19):3245-57. https://doi.org/10.1007/s00018-012-1092-4.

Sheen J. Molecular mechanisms underlying the differential expression of maize pyruvate, orthophosphate dikinase genes. Plant Cell. 1991;3(3):225-45. https://doi.org/10.1105/tpc.3.3.225.

Skadsen RW, Scandalios JG. Translational control of photo-induced expression of the Cat2 catalase gene during leaf development in maize. Proc Natl Acad Sci U S A. 1987;84(9):2785-9. https://doi.org/10.1073/pnas.84.9.2785.

Stewart LR, Willie K, Wijeratne S, Redinbaugh P, Massawe DP, Niblett CL, et al. Johnsongrass mosaic virus contributes to maize lethal necrosis in East Africa. Plant Dis. 2017;101(8):1455-62. https://doi.org/10.1094/PDIS-01-17-0136-RE.

Vranova E, Inze D, Van Breusegem F. Signal transduction during oxidative stress. J Exp Bot. 2002;53(372):1227-36. https://doi.org/10.1093/jxb/53.372.1227.

Wadsworth GJ, Scandalios JG. Differential expression of the maize catalase genes during kernel development - the role of steady-state mRNA levels. Dev Genet. 1989;10(4):304-10. https://doi.org/10.1002/dvg.1020100405.

Wang Q, Zhang C, Wang C, Qian Y, Li Z, Hong J, et al. Further characterization of maize chlorotic mottle virus and its synergistic interaction with sugarcane mosaic virus in maize. Sci Rep. 2017;7(1):39960. https://doi.org/10.1038/srep3 9960.

Willekens H, Inze D, van Montagu M, van Camp W. Catalases in plants. Mol Breed. 1995;1:207-28. https://doi.org/10.1007/BF02277422.

Xia Z, Zhao Z, Chen L, Li M, Zhou T, Deng C, et al. Synergistic infection of two viruses MCMV and SCMV increases the accumulations of both MCMV and MCMV-derived siRNAs in maize. Sci Rep. 2016;6(1):20520. https://doi.org/10.1 038/srep20520.

Yang T, Qiu L, Huang W, Xu Q, Zou J, Peng Q, et al. Chilli veinal mottle virus HCPro interacts with catalase to facilitate virus infection in Nicotiana tabacum. J Exp Bot. 2020;71(18):5656-68. https://doi.org/10.1093/jxb/eraa304.

You J, Hou S, Malik-Soni N, Xu Z, Kumar A, Rachubinski RA, et al. Flavivirus infection impairs peroxisome biogenesis and early antiviral signaling. J Virol. 2015;89(24):12349-61. https://doi.org/10.1128/JVI.01365-15.

Yuan HM, Liu WC, LU YT. CATALASE2 coordinates SA-mediated repression of both auxin accumulation and JA biosynthesis in plant defenses. Cell Host Microbe. 2017;21(2):143-55. https://doi.org/10.1016/j.chom.2017.01.007.

Zhan B, Lang F, Zhou T, Fan Z. Nuclear import of maize chlorotic mottle virus capsid protein is mediated by importin-a. Eur J Plant Pathol. 2016;146(4):88192. https://doi.org/10.1007/s10658-016-0966-y.

Zhang M, Li Q, Liu T, Liu L, Shen D, Zhu Y, et al. Two cytoplasmic effectors of Phytophthora sojae regulate plant cell death via interactions with plant catalases. Plant Physiol. 2015;167(1):164-75. https://doi.org/10.1104/pp.114.2 52437

Zhou YB, Liu C, Tang DY, Yan L, Wang D, Yang YZ, et al. The receptor-like cytoplasmic kinase STRK1 phosphorylates and activates CatC, thereby regulating $\mathrm{H}_{2} \mathrm{O}_{2}$ homeostasis and improving salt tolerance in rice. Plant Cell. 2018;30(5):1100-18. https://doi.org/10.1105/tpc.17.01000.

Zhu M, Chen Y, Ding XS, Webb SL, Zhou T, Nelson RS, et al. Maize Elongin C interacts with the viral genome-linked protein, VPg, of sugarcane mosaic virus and facilitates virus infection. New Phytol. 2014;203(4):1291-304. https:// doi.org/10.1111/nph.12890. 